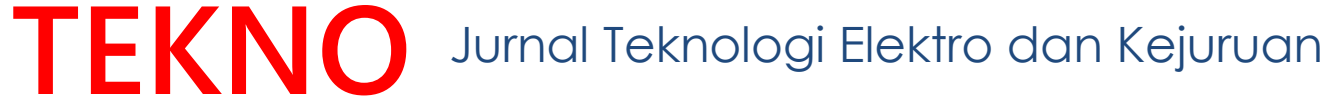

http://journal2.um.ac.id/index.php/tekno | ISSN 1693-8739

\section{Penerapan algoritma naïve bayes classifier untuk klasifikasi judul skripsi dan tugas akhir berdasarkan Kelompok Bidang Keahlian}

\author{
Utomo Pujianto ${ }^{1}$, Triyanna Widiyaningtyas ${ }^{2}$, Didik Dwi Prasetya ${ }^{3}$, Bintang Romadhon ${ }^{4}$ \\ 1. Universitas Negeri Malang, Indonesia | utomo.pujianto.ft@um.ac.id \\ 2. Universitas Negeri Malang, Indonesia | triyanaaw@um.ac.id \\ 3. Universitas Negeri Malang, Indonesia | didikdwi@um.ac.id \\ 4. Universitas Negeri Malang, Indonesia | bintang.arema@gmail.com
}

\begin{abstract}
Abstrak
SISINTA UM adalah sistem informasi berbasis web yang menampilkan data berkaitan dengan skripsi dan tugas akhir di Jurusan Teknik Elektro Fakultas Teknik Universitas Negeri Malang. Berdasarkan hasil observasi terhadap fitur SISINTA, diketahui bahwa judul yang ada belum terklasifikasi berdasarkan tema penelitiannya. Tujuan penelitian ini adalah untuk menerapkan dan menguji performa algoritma Naive Bayes Classifier dalam mengklasifikasi judul skripsi dan tugas akhir, berdasarkan tema penelitian dalam KBK di Jurusan Teknik Elektro FT UM. Model pengembangan yang digunakan penelitian ini adalah model waterfall. Model ini terdiri dari lima tahapan, yaitu: (1) analisis kebutuhan sistem, (2) desain sistem dan perangkat lunak, (3) implementasi dan pengujian unit, (4) integrasi dan pengujian sistem, (5) penerapan dan perawatan produk. Pengujian performa algoritma klasifikasi yang digunakan adalah teknik K-fold Cross Validation. Berdasarkan pengujian performa penerapan algoritma Naïve Bayes Classifiers menggunakan teknik K-Fold Cross Validation, dengan jumlah tahap pengujian sebanyak 10 kali, terhadap 1103 judul skripsi dan tugas akhir, didapatkan hasil rata-rata akurasi $94 \%$, presisi $80 \%$, dan recall 69\%.
\end{abstract}

\section{Kata Kunci}

KBK, Klasifikasi, Naive Bayes, Skripsi dan Tugas Akhir

TEKNO Vol. 27 Issue 1, p79-92 | Jurusan Teknik Elektro, Universitas Negeri Malang, Indonesia | Maret 2017

U. Pujianto, T. Widiyaningtyas, D.D. Prasetya, B. Romadhon | Penerapan algoritma naïve bayes classifier untuk klasifikasi judul... 


\section{TEKNO Jurnal Teknologi Elektro dan Kejuruan}

http://journal2.um.ac.id/index.php/tekno | ISSN 1693-8739

\section{Pendahuluan}

SISINTA UM adalah sistem informasi berbasis web yang berfungsi untuk menampilkan data yang berkaitan dengan skripsi dan tugas akhir milik mahasiswa Jurusan Teknik Elektro Fakultas Teknik Universitas Negeri Malang. Halaman web SISINTA menyediakan informasi berupa daftar judul, penulis, pembimbing, dan status seminar dari skripsi dan tugas akhir milik mahasiswa. Pengguna web SISINTA dapat menjadikan daftar judul yang ada, sebagai bahan referensi untuk pemilihan tema penelitian maupun pemilihan judul skripsi dan tugas akhir.

Daftar judul pada SISINTA disajikan dalam bentuk list yang terdiri dari sepuluh judul di setiap halaman, sehingga dalam pencarian referensi judul skripsi, pengguna harus membaca daftar judul di masing-masing halaman. Disediakan pula fitur pencarian berdasarkan kata kunci, dimana sistem hanya akan menampilkan judul yang berkaitan dengan kata kunci yang dimasukkan. Namun fitur yang ada ini masih belum bisa memenuhi kebutuhan pengguna yang ingin mencari referensi judul berdasarkan tema penelitiannya. Pencarian berdasarkan tema penelitian dapat memberikan referensi judul yang lebih luas tentang tema penelitian tertentu, dibandingkan dengan pencarian yang hanya menggunakan kata kunci.

Pencarian berdasarkan tema penelitian dapat dilakukan jika judul telah dikelompokkan terlebih dahulu, untuk itu diperlukan klasifikasi judul berdasarkan kategori penelitiannya. Berdasarkan Kelompok Bidang Keahlian (KBK) yang ada di Jurusan Teknik Elektro FT UM, lingkup penelitian yang ada secara umum terbagi menjadi: lingkup pendidikan vokasi, lingkup teknik elektro, dan lingkup teknik informatika. Setiap lingkup penelitian terdiri dari tiga program payung, sehingga ada sembilan program payung penelitian, yang terdiri dari: (1) manajemen vokasi dan pendidikan kejuruan, (2) kurikulum dan pembelajaran vokasi dan pendidikan kejuruan, (3) evaluasi pembelajaran vokasi dan pendidikan kejuruan, (4) kontrol, sistem cerdas, dan robotik, (5) sistem daya dan energi, (6) teknik elektronika, pengolahan sinyal, dan telekomunikasi, (7) sistem komputer, (8) rekayasa perangkat lunak, dan (9) teknologi informasi. Klasifikasi judul dapat dilakukan dengan dua cara, yakni secara manual (dilakukan oleh manusia) atau secara otomatis (dengan bantuan komputer). Kedua cara tersebut dapat diaplikasikan dengan mempertimbangkan keperluan dan situasi yang ada di lapangan. Dokumen berbentuk fisik memerlukan tenaga manusia untuk menata dan mengelompokkannya. Sedangkan pengelompokan dokumen digital dapat dilakukan dengan secara manual dan otomatis, namun akan lebih efisien jika dikelompokkan secara otomatis.

Klasifikasi dokumen secara otomatis, dapat dibagi menjadi tiga jenis, yaitu: (1) supervised document classification (klasifikasi dokumen dengan pengawasan) dimana dalam penerapannya masih memerlukan pendampingan dari manusia, (2) unsupervised document classification (klasifikasi dokumen tanpa pengawasan) dimana penerapannya dilakukan tanpa bantuan manusia (disebut juga dengan clustering), (3) semi-supervised document classification (klasifikasi dokumen dengan semi-pengawasan) dimana pengklasifikasian masih memerlukan kontribusi manusia di beberapa bagian tertentu.

TEKNO Vol. 27 Issue 1, p79-92 | Jurusan Teknik Elektro, Universitas Negeri Malang, Indonesia | Maret 2017

U. Pujianto, T. Widiyaningtyas, D.D. Prasetya, B. Romadhon | Penerapan algoritma naïve bayes classifier untuk klasifikasi judul... 


\section{TEKNO Jurnal Teknologi Elektro dan Kejuruan}

http://journal2.um.ac.id/index.php/tekno | ISSN 1693-8739

Naive Bayes Classifier (NBC) adalah salah satu dari algoritma supervised document classification yang sederhana namun efisien. Model probabilistik dari algoritma ini didasarkan pada teori Bayes. Naive Bayes Classifier telah diterapkan di berbagai bidang, seperti: kedokteran, perbankan, perpustakaan, instansi perkantoran, dll. Permasalahan klasifikasi yang sering dipecahkan dengan NBC antara lain seperti: diagnosa penyakit dan pembuatan keputusan pada prosedur perawatannya, penyaringan spam pada email clients, analisis sentimen, prediksi kelayakan calon nasabah asuransi, dll.

Penelitian ini membahas penerapan Naive Bayes Classifier untuk mengklasifikasi judul skripsi dan tugas akhir berdasarkan KBK di Jurusan Teknik Elektro FT UM. Pemilihan ketegori tersebut didasarkan pada kebutuhan untuk mendapatkan referensi judul sesuai tema penelitian yang diinginkan pengguna. Dengan adanya sistem klasifikasi judul ini, diharapkan dapat mempermudah pengelompokan judul yang ada, serta meningkatkan efisiensi waktu ketika dilakukan pencarian judul skripsi berdasarkan tema penelitiannya.

\section{Metode}

Prosedur penelitian dan pengembangan ini mengadaptasi model pengembangan waterfall, menurut Sommerville (2011) model pengembangan waterfall terdiri dari langkah-langkah berikut:

1. Definisi Kebutuhan Perangkat Lunak

Berdasarkan observasi yang telah dilakukan pada fungsionalitas web SISINTA, dapat diketahui bahwa data berupa judul skripsi dan tugas akhir yang ada, belum dikelompokkan berdasarkan tema penelitiannya. Maka disimpulkan bahwa perlu ditambahkan fitur pengkategorian pada judul berdasarkan tema penelitiannya. Diharapkan dengan adanya klasifikasi judul, dapat memudahkan pengguna dalam mencari referensi judul skripsi atau tugas akhir berdasarkan tema yang diinginkan.

Pengembangan ini akan berfokus pada penerapan algoritma Naive Bayes Classifier untuk mengelompokkan judul skripsi/tugas akhir pada web SISINTA TE FT UM. Judul akan dikelompokkan ke dalam sembilan kategori berdasarkan tema penelitian di KBK di Jurusan Teknik Elektro FT UM.

Dalam tahapan data mining yang akan dilakukan, dibutuhkan data training untuk pembentukan classifier. Data training diambil dari data skripsi/tugas akhir milik Jurusan TE FT UM terdahulu. Jumlah data training untuk tiap kelas/kategori adalah sekitar 100 judul. Pelabelan judul yang dijadikan data training, ditentukan berdasarkan deskripsi tema penelitian yang tersaji pada berkas KBK Jurusan TE FT UM tahun 2015.

2. Desain Sistem dan Perangkat Lunak

Desain sistem pada penelitian ini terdiri dari pembuatan flowchart (alur proses), data flow diagam (DFD), dan mockup (perancangan desain antarmuka). Gambar 1 adalah flowchart yang menggambarkan urutan proses klasifikasi teks, yang secara umum terbagi menjadi dua tahapan, yaitu: tahap training dan tahap klasifikasi.

TEKNO Vol. 27 Issue 1, p79-92 | Jurusan Teknik Elektro, Universitas Negeri Malang, Indonesia | Maret 2017

U. Pujianto, T. Widiyaningtyas, D.D. Prasetya, B. Romadhon | Penerapan algoritma naïve bayes classifier untuk klasifikasi judul... 


\section{TEKNO Jumal Teknologi Elekro dan Kejurvan}

http://journal2.um.ac.id/index.php/tekno | ISSN 1693-8739

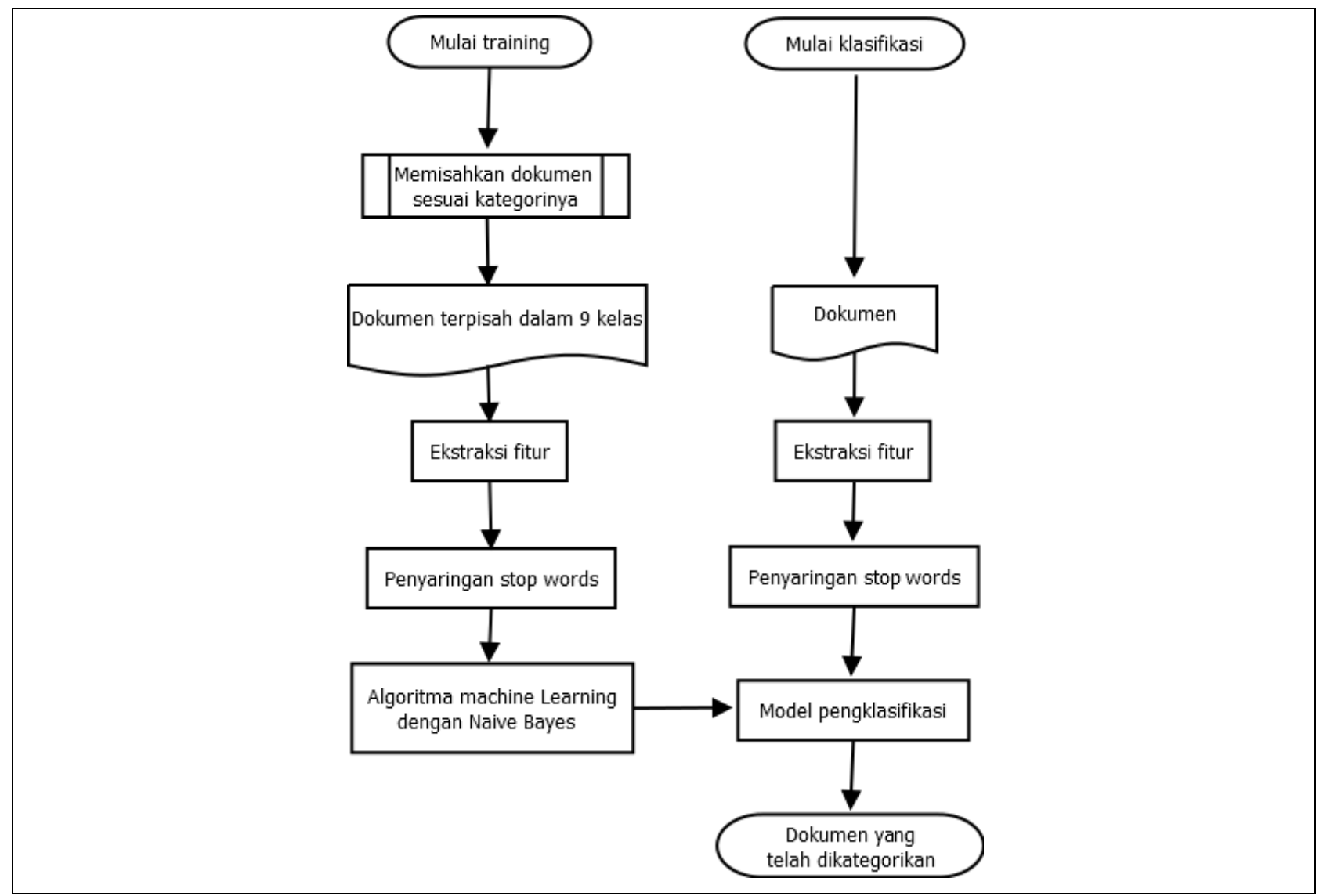

Gambar 1. Tahapan Klasifikasi Dokumen

Tahapan klasifikasi dokumen pada sistem digambarkan oleh Gambar 1. Pada tahap training, judul skripsi dan tugas akhir dikelompokkan ke dalam sembilan kategori yang telah ditentukan, kemudian dianalisis guna membentuk aturan klasifikasi (classifier). Pada tahap klasifikasi, sebuah dokumen baru yang belum dikenali dikelompokkan ke dalam kategori tertentu menggunakan classifier.

Data flow diagram dari sistem klasifikasi judul skripsi dan tugas akhir ditampilkan pada Gambar 2.

3. Implementasi dan Pengujian Unit

Pada tahap ini, dilakukan pembangunan sistem berdasarkan definisi kebutuhan dan rancangan sistem. Sistem ini dibangun dengan berbasis web, menggunakan bahasa pemrograman PHP, pada sisi tampilan menggunakan HTML5 dan CSS3. Pada sisi penyimpanan menggunakan MySQL. Sistem yang dibangun kemudian diuji sebagai unitunit program yang terpisah. Metode pengujian unit memakai metode basis path, yaitu salah satu metode pengujian white box. Metode basis path memungkinkan penguji untuk

TEKNO Vol. 27 Issue 1, p79-92 | Jurusan Teknik Elektro, Universitas Negeri Malang, Indonesia | Maret 2017

U. Pujianto, T. Widiyaningtyas, D.D. Prasetya, B. Romadhon | Penerapan algoritma naïve bayes classifier untuk klasifikasi judul... 


\section{TEKNO Junnal Teknologi Elekrro dan Kejuruan}

http://journal2.um.ac.id/index.php/tekno | ISSN 1693-8739

mendapatkan ukuran kompleksitas logis dari desain prosedural dan menggunakannya untuk menentukan basis set dari aliran eksekusi. Pada metode ini, control flow dilambangkan dengan notasi flow graph (disebut juga dengan program graph) yang ditampilkan pada Gambar 3.

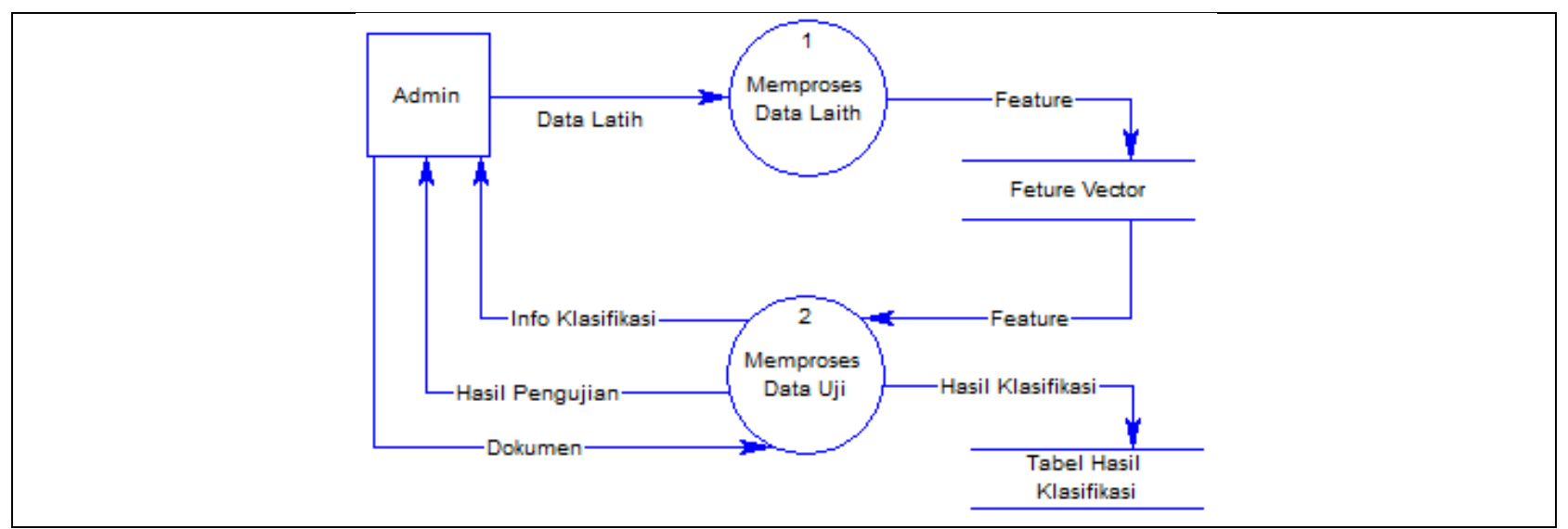

Gambar 2. DFD Level 1

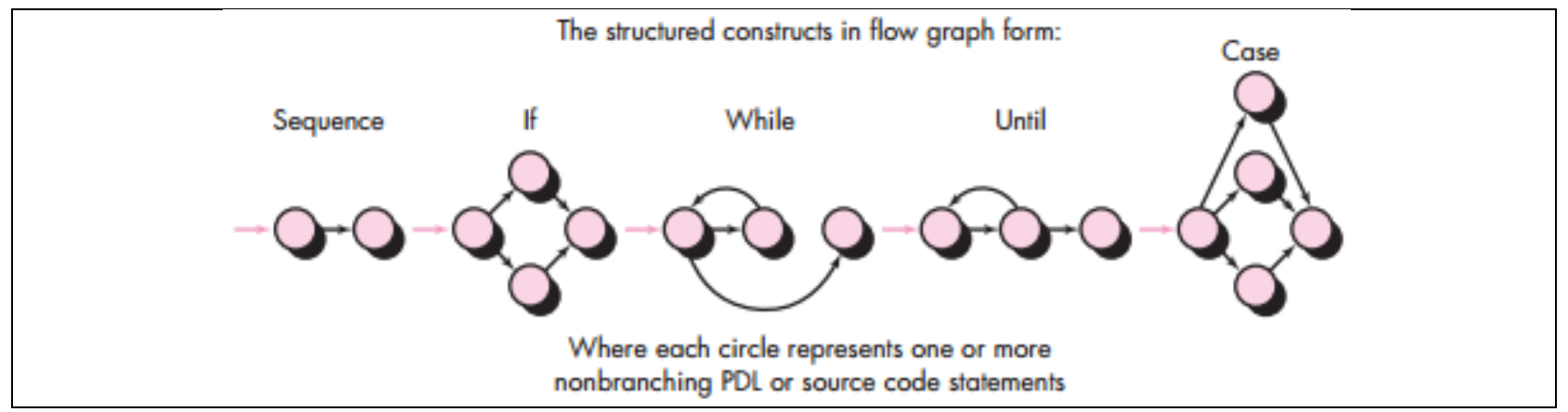

Gambar 3. Notasi Flow Graph (Sumber: Pressman 2010)

Pengujian white box yang dilakukan, difokuskan pada prosedur pembentukan classifier dan prosedur klasifikasi dokumen. Tahapan pengujian kedua prosedur tersebut masing-masing adalah sebagai berikut:

a) Menentukan diagram alir masing-masing prosedur.

Langkah pertama dalam proses klasifikasi dokumen adalah membentuk classifier model atau disebut juga dengan proses training. Dokumen yang dijadikan data training harus dikelompokkan dahulu secara manual, barulah diinputkan ke sistem untuk diproses. Proses training terdiri dari tokenisasi (pemecahan kalimat menjadi satuan kata), penghilangan stop words (menghilangkan kata yang tidak penting), dan pembentukan vocabulary (vektor atribut yang berisi daftar kata dan frekuensi kemunculannya). Vocabulary yang terbentuk, nantinya akan dijadikan acuan dalam perhitungan probabilitas pada proses klasifikasi

TEKNO Vol. 27 Issue 1, p79-92 | Jurusan Teknik Elektro, Universitas Negeri Malang, Indonesia | Maret 2017

U. Pujianto, T. Widiyaningtyas, D.D. Prasetya, B. Romadhon | Penerapan algoritma naïve bayes classifier untuk klasifikasi judul... 


\section{TEKNO Jurnal Teknologi Elektro dan Kejuruan}

http://journal2.um.ac.id/index.php/tekno | ISSN 1693-8739

nantinya. Gambar 4 menunjukkan flowchart dari prosedur pembentukan classifier model atau vocabulary.

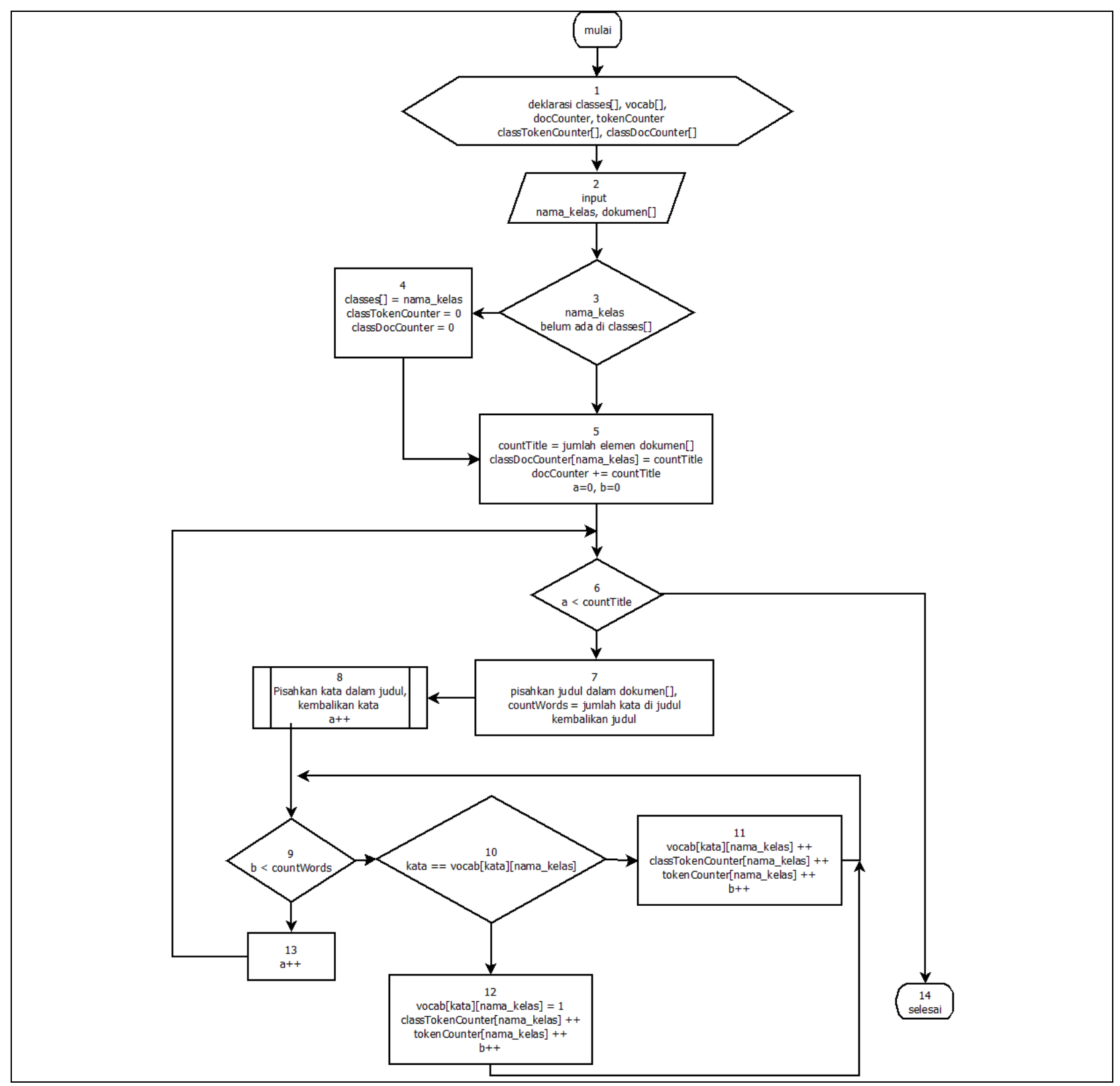

Gambar 4. Flowchart Pembentukan Classifier

Langkah selanjutnya adalah proses klasifikasi dokumen, yaitu pengelompokan dokumen berdasarkan perhitungan probabilitas menggunakan algoritma Naïve Bayes. Proses

TEKNO Vol. 27 Issue 1, p79-92 | Jurusan Teknik Elektro, Universitas Negeri Malang, Indonesia | Maret 2017

U. Pujianto, T. Widiyaningtyas, D.D. Prasetya, B. Romadhon | Penerapan algoritma naïve bayes classifier untuk klasifikasi judul... 


\section{TEKNO Jurnal Teknologi Elektro dan Kejuruan}

http://journal2.um.ac.id/index.php/tekno | ISSN 1693-8739

klasifikasi dokumen (judul skripsi dan tugas akhir) terdiri dari beberapa langkah, yaitu: tokenisasi, perhitungan prior probability, class probability, dan posterior probabiility.

Persamaan untuk menghitung prior probability ditunjukkan oleh Pers. (1).

$$
\hat{P}\left(\omega_{j}\right)=\frac{N_{\omega_{j}}}{N_{c}}
$$

Keterangan:

- $\quad \mathrm{N}_{\mathrm{wj}}$ : Total sampel pada kelas $\mathbf{w}_{\mathrm{j}}$.

- $\mathrm{N}_{\mathrm{C}}$ : Total seluruh sampel.

Rumus class probability adalah sbb:

$$
\hat{P}\left(x_{i} \mid \omega_{j}\right)=\frac{\sum t f\left(x_{i}, d \in \omega_{j}\right)+\alpha}{\sum N_{d \in \omega j}+\alpha \cdot V}
$$

Keterangan:

- $\quad x_{i}$ : kata dari sampel dalam vocabulary

- $\sum t f\left(x_{i}, d \in \omega_{j}\right):$ kemunculan kata $\mathbf{x}_{\mathrm{i}}$ dalam kelas $\mathbf{w}_{\mathrm{j}}$.

- $\sum N_{d \in \omega j}$ : Total seluruh kata pada kelas $\mathbf{w}_{\mathrm{j}}$.

- $\alpha$ : Parameter smoothing tambahan ( $\alpha=1$ untuk Laplace smoothing)

- V : Ukuran dari vocabulary (jumlah kata unik dalam vocabulary).

Pada rumus class probability di atas telah ditambahkan sebuah parameter smoothing, lebih tepatnya Laplace smoothing $(\alpha=1)$. Hal ini dilakukan untuk menghindari adanya zero probabilities. Contoh kasus zero probabilities ialah ketika ada kata dari sampel yang ternyata tidak ditemukan dalam vocabulary, maka class-conditional probability-nya akan bernilai 0 . Jika class-conditional probability bernilai nol, maka posterior probability-nya juga akan bernilai 0 , mengingat porterior probability adalah hasil kali antara class-condional probability dengan prior probability. Penambahan parameter smoothing akan menjadikan suatu kata dianggap muncul minimal satu kali.

Sedangkan untuk menghitung nilai posterior probability adalah dengan mengalikan prior probability dengan class probability. Perhitungan dilakukan sesuai dengan jumlah kategori, kemudian diakhir proses nilai posterior akan dibandingkan dan hasil terbesar akan dijadikan acuan penentuan kategori dari dokumen yang diuji. Gambar 5 menunjukkan flowchart dari prosedur klasifikasi dokumen.

TEKNO Vol. 27 Issue 1, p79-92 | Jurusan Teknik Elektro, Universitas Negeri Malang, Indonesia | Maret 2017

U. Pujianto, T. Widiyaningtyas, D.D. Prasetya, B. Romadhon | Penerapan algoritma naïve bayes classifier untuk klasifikasi judul... 


\section{TEKNO Jurnal Teknologi Elektro dan Kejuruan}

http://journal2.um.ac.id/index.php/tekno | ISSN 1693-8739

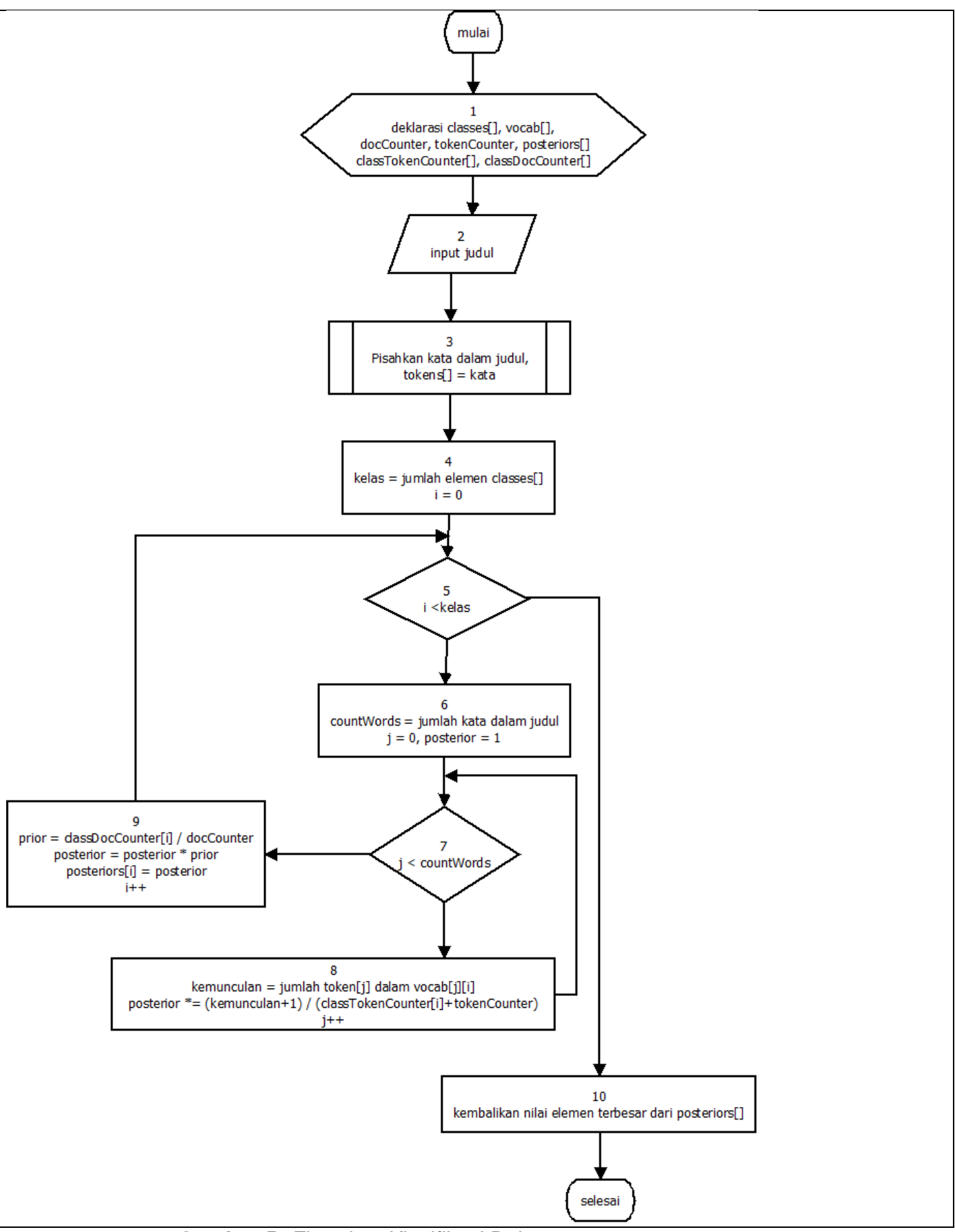

Gambar 5. Flowchart Klasifikasi Dokumen

b) Menentukan flow graph berdasarkan flow chart yang telah dibuat. Gambar 6 menunjukkan flow graph yang terbentuk dari flow chart pada Gambar 4.

TEKNO Vol. 27 Issue 1, p79-92 | Jurusan Teknik Elektro, Universitas Negeri Malang, Indonesia | Maret 2017

U. Pujianto, T. Widiyaningtyas, D.D. Prasetya, B. Romadhon | Penerapan algoritma naïve bayes classifier untuk klasifikasi judul... 


\section{TEKNO Jurnal Teknologi Elektro dan Kejuruan}

http://journal2.um.ac.id/index.php/tekno | ISSN 1693-8739

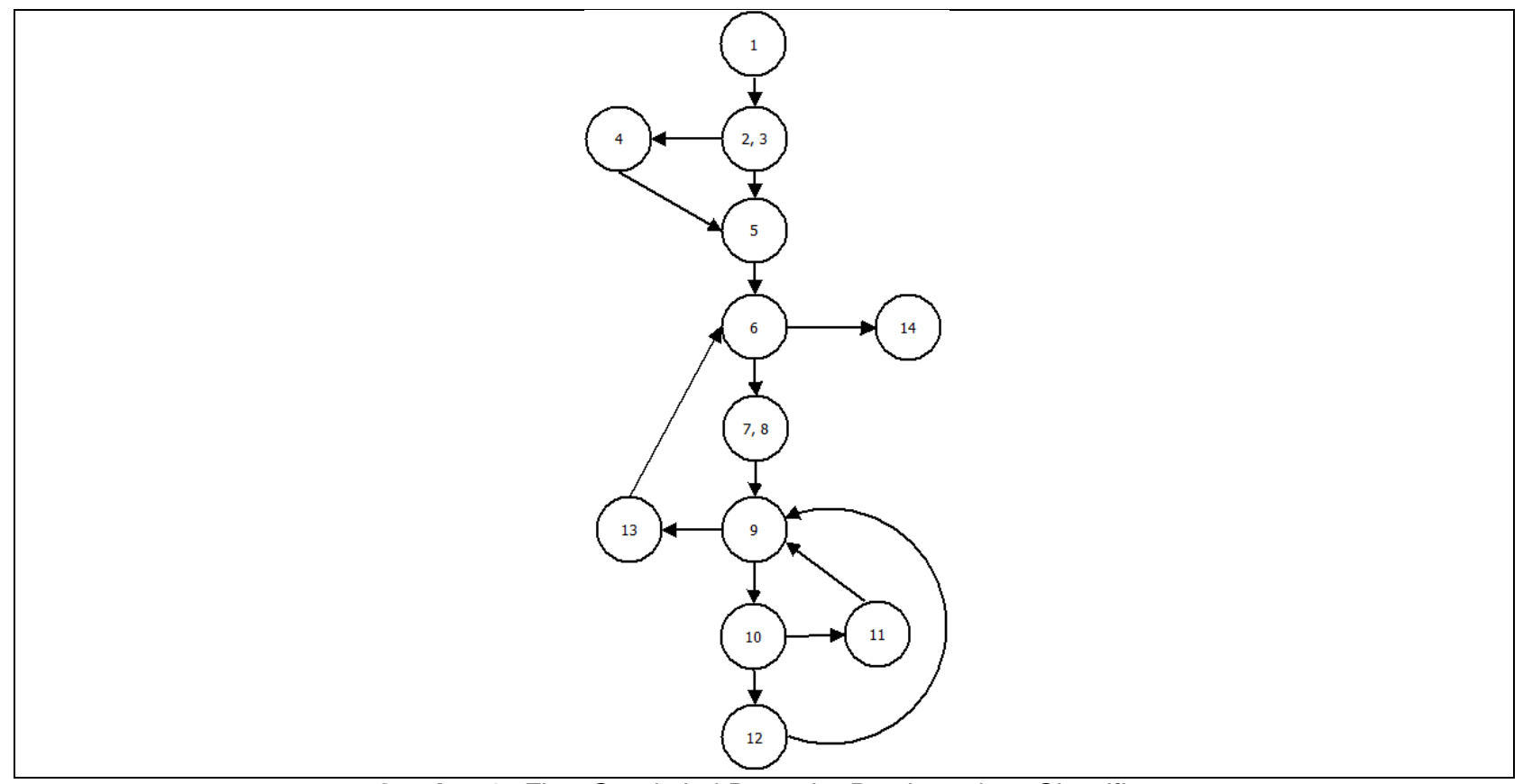

Gambar 6. Flow Graph dari Prosedur Pembentukan Classifier.

Gambar 7 menunjukkan flow graph yang terbentuk dari flow chart pada Gambar 5.

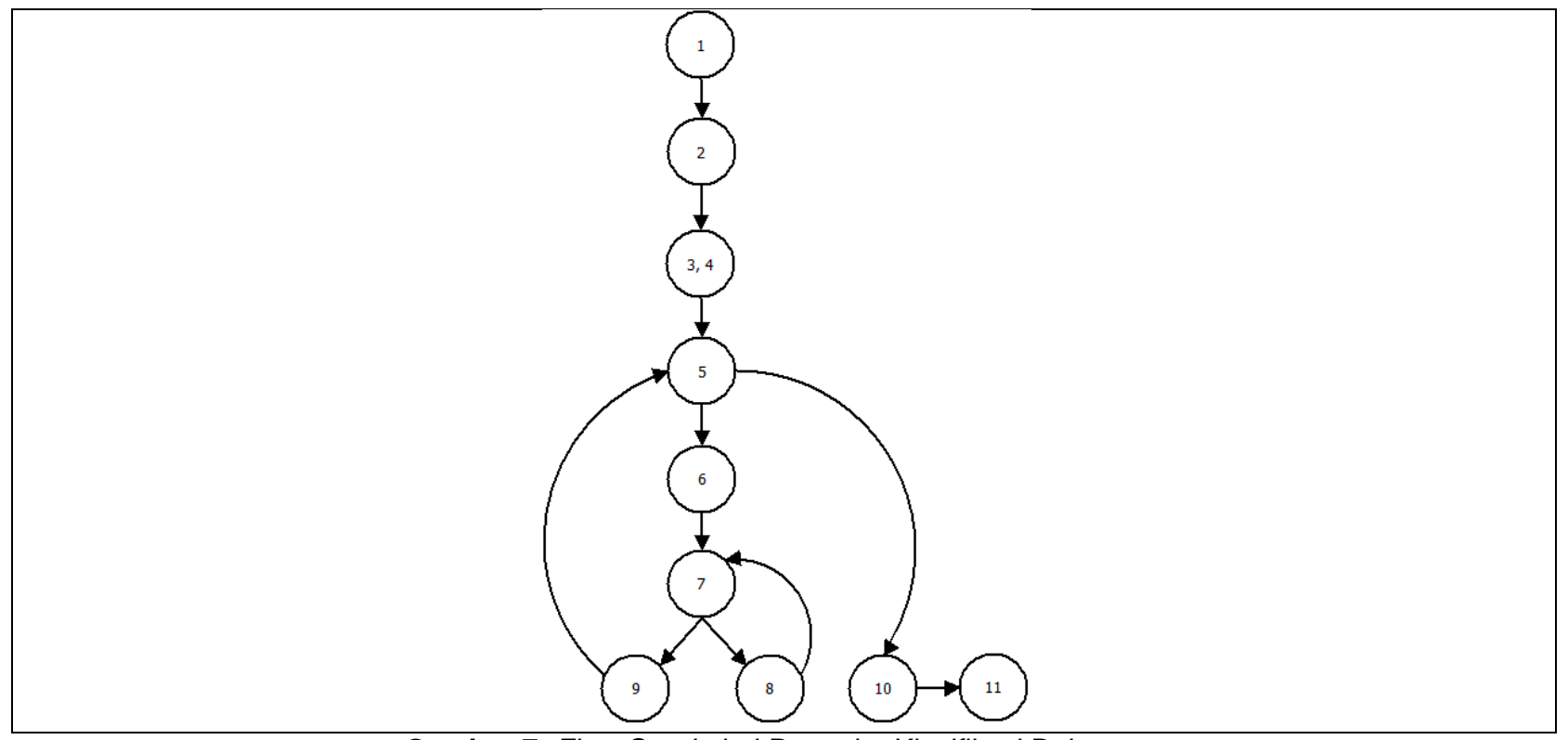

Gambar 7. Flow Graph dari Prosedur Klasifikasi Dokumen.

TEKNO Vol. 27 Issue 1, p79-92 | Jurusan Teknik Elektro, Universitas Negeri Malang, Indonesia | Maret 2017

U. Pujianto, T. Widiyaningtyas, D.D. Prasetya, B. Romadhon | Penerapan algoritma naïve bayes classifier untuk klasifikasi judul... 


\section{TEKNO Jurnal Teknologi Elektro dan Kejuruan}

http://journal2.um.ac.id/index.php/tekno | ISSN 1693-8739

c) Menentukan cyclomatic complexity dan independent path.

Berdasarkan flow graph pada Gambar 6, maka cyclomatic complexity dari prosedur pembentukan classifier adalah berjumlah 5 . Jumlah tersebut dihitung berdasarkan jumlah region, atau area yang dikelilingi oleh edge. Kemudian independent path yang akan diuji adalah sebagai berikut:

- $\quad$ Path $1=1-2-3-4-5$

- $\quad$ Path 2 = 1-2-3-5-6-7-8-9-10-11

- $\quad$ Path $3=1-2-3-5-6-7-8-9-10-12$

- $\quad$ Path $4=1-2-3-5-6-7-8-9-10-12-13$

- $\quad$ Path $5=1-2-3-5-6-7-8-9-10-12-13-14$

Berdasarkan jumlah region pada flow graph yang ditunjukkan oleh Gambar 7, maka cyclomatic complexity dari prosedur pembentukan klasifikasi dokumen adalah berjumlah 3 . Independent path yang akan diuji adalah sebagai berikut:

- $\quad$ Path 1 = 1-2-3-4-5-6-7-8

- $\quad$ Path $2=1-2-3-4-5-6-7-8-9$

- $\quad$ Path $3=1-2-3-4-5-6-7-8-9-5-10-11$

d) Menentukan test case berdasarkan independent path.

Penentuan test case dimaksudkan untuk menguji kebenaran logika masing-masing independent path minimal sekali. Biasanya dilakukan pengujian dengan memasukkan variabel yang berbeda tipe, kemudian diamati apakah terjadi error. Karena sistem ini hanya menginputkan variabel berjenis teks, maka untuk menguji masing-masing path dilakukan pencocokan hasil perhitungan dengan prosedur manual dan hasil perhitungan yang dihasilkan sistem. Kemudian sistem akan dinyatakan lulus uji jika hasil perhitungan manual sama dengan hasil perhitungan sistem.

4. Integrasi dan Pengujian Sistem

Pada tahap ini, satuan unit program diintegrasikan, kemudian diuji sebagai satu sistem yang utuh. Pengujian bertujuan untuk memastikan bahwa sistem telah memenuhi kebutuhan dan melihat kinerja dari penerapan algoritma klasifikasi.

Teknik pengujian yang dipilih untuk mengukur performa dari penerapan algoritma Naive Bayes Classifier adalah teknik K-Fold Cross Validation. Pada pengujian K-Fold CrossValidation, training data set dibagi ke dalam lipatan sebanyak $k$ secara acak tanpa penggantian, dimana lipatan dengan jumlah $k-1$ digunakan sebagai model training, sedangkan 1 lipatan yang tersisa digunakan untuk pengujian. Prosedur ini diulang sebanyak $k$ kali sehingga nantinya akan didapat model dan perhitungan performa sebanyak $k$ (Raschka, 2015). Ilustrasi k-fold cross-validation ditunjukkan oleh Gambar 8.

TEKNO Vol. 27 Issue 1, p79-92 | Jurusan Teknik Elektro, Universitas Negeri Malang, Indonesia | Maret 2017

U. Pujianto, T. Widiyaningtyas, D.D. Prasetya, B. Romadhon | Penerapan algoritma naïve bayes classifier untuk klasifikasi judul... 


\section{TEKNO Jumal Teknologi Eektro dan Kejuruon}

http://journal2.um.ac.id/index.php/tekno | ISSN 1693-8739

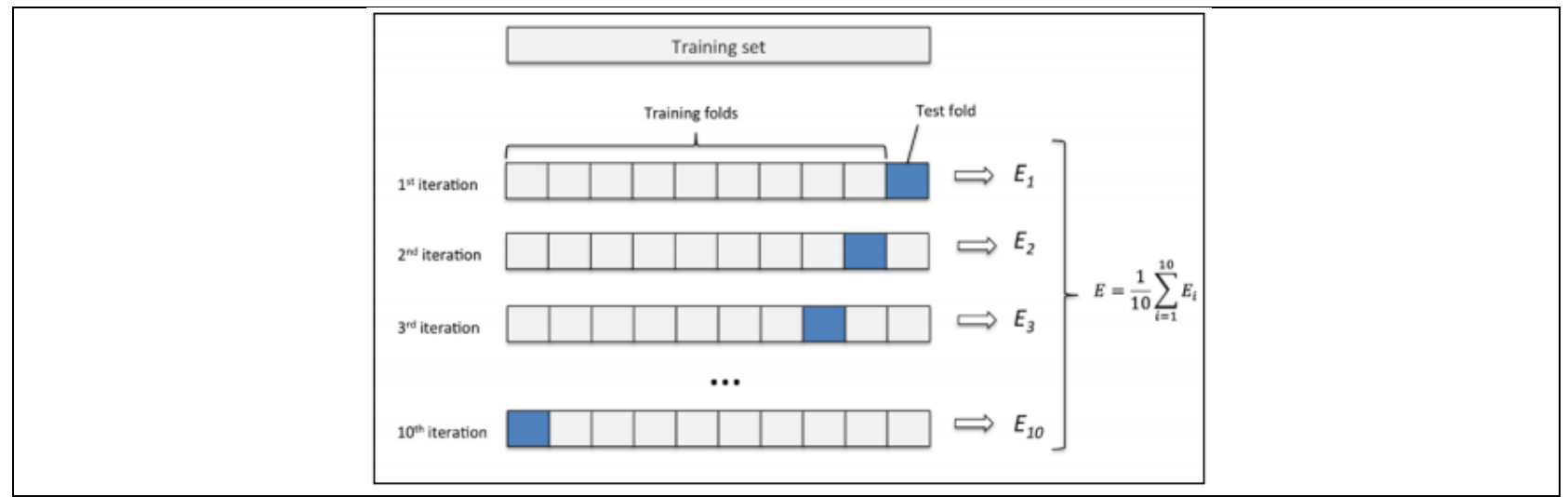

Gambar 8. Ilustrasi K-Fold Cross-Validation (Raschka, 2015)

Jumlah data set yang digunakan pada percobaan ini adalah sekitar 1050, terdiri dari 100 data untuk setiap kategorinya. Pemilihan sampel yang digunakan sebagai data uji dilakukan secara acak dengan mengambil perwakilan dari setiap kategori, hal ini dilakukan agar data sampel dari masing-masing kategori tersebar merata. Data set diperoleh dari judul skripsi dan tugas akhir yang ada pada web SISINTA, namun tidak menutup kemungkinan diambil dari sumber lain yang relevan, mengingat beberapa kategori tema penelitian yang ada di web SISINTA masih memiliki koleksi judul yang sedikit.

Pada setiap ekperimen akan dihitung jumlah prediksi true positive (anggota kelas yang secara benar diprediksi sebagai anggota kelas), true negative (non-anggota kelas yang secara benar diprediksi sebagai non-anggota kelas), false positive (non-anggota kelas yang secara salah diprediksi sebagai anggota kelas), dan false negative (anggota kelas yang secara salah diprediksi sebagai non-anggota kelas). Perhitungan prediksi tersebut kemudian ditampung dalam confusion matrix. Confusion matrix adalah kotak berisi matriks yang menggambarkan jumlah dari prediksi true positive (TP), true negative (TN), false positive (FP), dan false negative (FN) dari sebuah classifier, Gambar 9. menunjukkan ilustrasi dari confusion matrix.

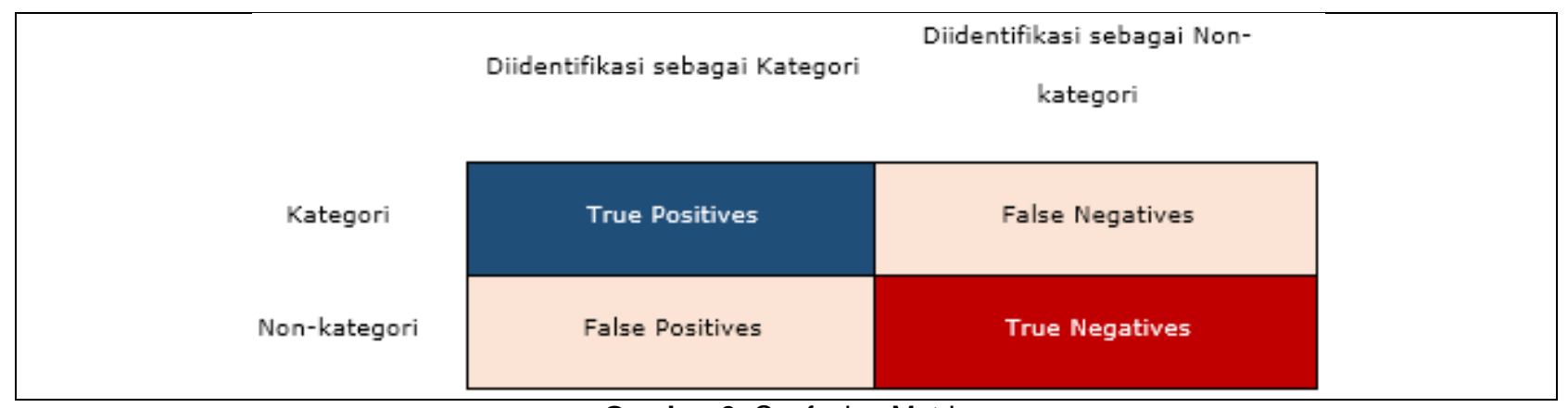

Gambar 9. Confusion Matrix

TEKNO Vol. 27 Issue 1, p79-92 | Jurusan Teknik Elektro, Universitas Negeri Malang, Indonesia | Maret 2017

U. Pujianto, T. Widiyaningtyas, D.D. Prasetya, B. Romadhon | Penerapan algoritma naïve bayes classifier untuk klasifikasi judul... 


\section{TEKNO Jumal Teknologi Eekrto dan Kejuruan}

http://journal2.um.ac.id/index.php/tekno | ISSN 1693-8739

Berdasarkan data yang terekam dalam confusion matrix, akan dilakukan identitifikasi terhadap performa penerapan algoritma klasifikasi, yakni menghitung nilai accuracy, precision, dan recall. Accuracy adalah persentase dari total dokumen yang diidentifikasi dengan benar. Precision adalah tingkat ketepatan jawaban yang diberikan sistem, atas informasi yang diminta oleh pengguna. Sedangkan, recall adalah efektifitas classifier dalam mengidentifikasi label positif, disebut juga dengan True Positive Rate.

Menurut (Sokolova \& Lapalme, 2009) rumus perhitungan nilai accuracy, precision, dan recall dalam kasus multiclass classification adalah sbb:

Rumus perhitungan nilai accuracy:

$$
\frac{\sum_{i=1}^{l} \frac{t p_{i}+t n_{i}}{t p_{i}+f n_{i}+f p_{i}+t n_{i}}}{l}
$$

Rumus perhitungan precision:

$$
\frac{\sum_{i=1}^{l} \frac{t p_{i}}{t p_{i}+f p_{i}}}{l}
$$

Rumus perhitungan recall:

$$
\frac{\sum_{i=1}^{l} \frac{t p_{i}}{t p_{i}+f n_{i}}}{l}
$$

\section{Keterangan:}

- $t p_{i}$ : nilai True Positive dari kategori ke-i

- $t n_{i}$ : nilai True Negative kategori ke-i

- $f n_{i}$ : nilai False Negative kategori ke-i

- $f p_{i}$ : nilai False Positive kategori ke-i

- $\quad l$ : Jumlah kategori

- $\quad \sum_{i=1}^{l} \frac{t p_{i}+t n_{i}}{t p_{i}+f n_{i}+f p_{i}+t n_{i}}:$ Jumlah accuracy dari semua kategori

- $\quad \sum_{i=1}^{l} \frac{t p_{i}}{t p_{i}+f p_{i}}:$ Jumlah precision dari semua kategori

- $\quad \sum_{i=1}^{l} \frac{t p_{i}}{t p_{i}+f n_{i}}$ : Jumlah recall dari seluruh kategori.

Dapat dijelaskan bahwa nilai accuracy, precision, dan recall dalam kasus multiclass classification, diperoleh dari nilai rata-rata accuracy, precision, dan recall dari semua kategori. 


\section{TEKNO Jumal Teknologi Eektro dan Kejuruon}

http://journal2.um.ac.id/index.php/tekno | ISSN 1693-8739

\section{Penggunaan dan Pemeliharaan}

Pada tahap ini, sistem yang dibuat telah diimplementasikan atau dioperasikan secara nyata oleh pengguna. Pemeliharaan sistem dilakukan jika ditemui error yang belum ditemui pada tahap pengujian sistem sebelumnya.

\section{Hasil}

Hasil pengujian unit menghasilkan kesimpulan bahwa sistem klasifikasi judul skripsi dan tugas akhir telah berjalan sesuai dengan algoritma yang ditentukan. Hasil dari pengujian dengan metode basis path pada pengujian white box terhadap prosedur pembentukan vocabulary ditampilkan pada Tabel 1.

Tabel 1. Hasil Pengujian Setiap Path pada Prosedur Pembentukan Vocabulary

\begin{tabular}{cll}
\hline No & Keterangan & Status \\
\hline 1 & Deklarasi awal variabel dan deklarasi nama kategori & Sukses \\
2 & Mentokenisasi judul, menginkremen jumlah kata ke-i ke vocabulary & Sukses \\
3 & Mentokenisasi judul, menambahkan sebuah kata baru ke vocabulary & Sukses \\
4 & Kembali ke langkah tokenisasi judul & Sukses \\
5 & Mengakhiri proses training, jika semua judul telah diolah oleh sistem & Sukses \\
\hline
\end{tabular}

Sedangkan hasil dari pengujian dengan metode basis path pada pengujian white box terhadap prosedur pembentukan klasifikasi dokumen ditampilkan pada Tabel 2.

Tabel 2. Hasil Pengujian Setiap Path pada Prosedur Klasifikasi Dokumen

\begin{tabular}{cll}
\hline No & Keterangan & Status \\
\hline 1 & Deklarasi variabel, menghitung class probability masing-masing kata & Sukses \\
2 & Menghitung posterior probability & Sukses \\
3 & Menentukan kategori suatu judul berdasarkan nilai posterior terbesar & Sukses \\
\hline
\end{tabular}

Tabel 3. Hasil Pengujian Performa

\begin{tabular}{cccc}
\hline Tahap Pangujian & Akurasi (\%) & Presisi (\%) & Recall (\%) \\
\hline 1 & 94.29 & 82.50 & 71.74 \\
2 & 94.76 & 85.09 & 73.25 \\
3 & 92.80 & 79.60 & 64.18 \\
4 & 93.29 & 76.34 & 66.96 \\
5 & 94.92 & 83.65 & 72.53 \\
6 & 94.34 & 83.21 & 70.61 \\
7 & 93.50 & 75.05 & 66.90 \\
8 & 94.92 & 84.01 & 73.24 \\
9 & 94.23 & 79.52 & 71.29 \\
10 & 93.16 & 76.92 & 66.22 \\
\hline Rata-rata & $\mathbf{9 4 . 0 2}$ & $\mathbf{8 0 . 5 8}$ & $\mathbf{6 9 . 6 9}$ \\
\hline
\end{tabular}

TEKNO Vol. 27 Issue 1, p79-92 | Jurusan Teknik Elektro, Universitas Negeri Malang, Indonesia | Maret 2017

U. Pujianto, T. Widiyaningtyas, D.D. Prasetya, B. Romadhon | Penerapan algoritma naïve bayes classifier untuk klasifikasi judul... 


\section{TEKNO Jurnal Teknologi Elektro dan Kejuruan}

http://journal2.um.ac.id/index.php/tekno | ISSN 1693-8739

Data hasil pengujian performa klasifikasi oleh sistem, disajikan dalam data kuantitatif yang merepresentasikan performa penerapan algoritma Naïve Bayes. Data hasil pengujian performa diperoleh dari 10 kali tahap pengujian menggunakan teknik K-Fold Cross Validation. Total sampel yang dipakai dalam sesi uji performa adalah sebanyak 1052 judul skripsi dan tugas akhir. Tabel 3 menyajikan hasil pengujian performa dari salah satu sesi pengujian. Hasil yang telah didapatkan ini dapat berubah jika dilakukan pengujian ulang, hal ini terjadi karena adanya pengacakan pada data latih dan data uji, meski demikian perbedaannya tidak akan mempunyai selisih yang signifikan.

\section{Kesimpulan}

Berdasarkan uraian hasil penelitian, maka dapat dikemukakan kesimpulan sebagai berikut:

- Sistem klasifikasi yang dikembangkan telah berhasil mengelompokkan judul skripsi dan tugas akhir berdasarkan Kelompok Bidang Keahlian (KBK) di Jurusan Teknik Elektro FT UM.

- Pengujian performa penerapan algoritma Naïve Bayes Classifiers menggunakan teknik K-Fold Cross Validation, dengan jumlah tahap pengujian sebanyak 10 kali, terhadap 1103 judul skripsi dan tugas akhir, didapatkan hasil rata-rata akurasi $94 \%$, presisi $80 \%$, dan recall $69 \%$.

\section{Daftar Rujukan}

Pressman, R. 2010. Software Engineering A Practitioner's Approach 7th Edition. New York: McGraw-Hill.

Raschka, S. 2015. Naive Bayes and Text Classification I Introduction and Theory. New York: Cornell University Library. Dari Cornell University Library, (Online), (http://arxiv.org/pdf/1410.5329v3.pdf), diakses pada 10 Desember 2016.

Raschka, S. 2015. Python Machine Learning. Birmingham: Packt Publishing Ltd.

Sokolova, M., \& Lapalme, G. 2009. A Systematic Analysis of Performance Measure for Classification Tasks. Information Processing and Management, (Online), 1 (45): 427-437, (http://atour.iro.umontreal.ca/rali/sites/default/files/publis/SokolovaLapalme-JIPM09.pdf), diakses pada 19 Januari 2017.

Sommerville, I. 2011. Software Engineering 9th. Boston: Pearson Education.

Tim Penyusun. 2015. Kelompok Bidang Keahlian Jurusan Teknik Elektro FT UM. Malang: Jurusan Teknik Elektro FT UM. 